\title{
Coulisses
}

Revue de théâtre

8 | Eté 1993

Varia

\section{Repères bibliographiques : Shakespeare (1564-1619)}

\section{(2) OpenEdition \\ Journals}

Édition électronique

URL : http://journals.openedition.org/coulisses/2615

DOI : $10.4000 /$ coulisses.2615

ISSN : 2546-9460

Éditeur

Presses universitaires de Franche-Comté

\section{Édition imprimée}

Date de publication : 1 juillet 1993

Pagination : 60-61

ISSN : 1150-594X

\section{Référence électronique}

«Repères bibliographiques: Shakespeare (1564-1619)», Coulisses [En ligne], 8 | Eté 1993, mis en ligne le 15 mars 2019, consulté le 29 octobre 2019. URL : http://journals.openedition.org/coulisses/2615 ; DOI : 10.4000/coulisses.2615

Ce document a été généré automatiquement le 29 octobre 2019

Coulisses 


\section{Repères bibliographiques : Shakespeare (1564-1619)}

\section{Shakespeare}

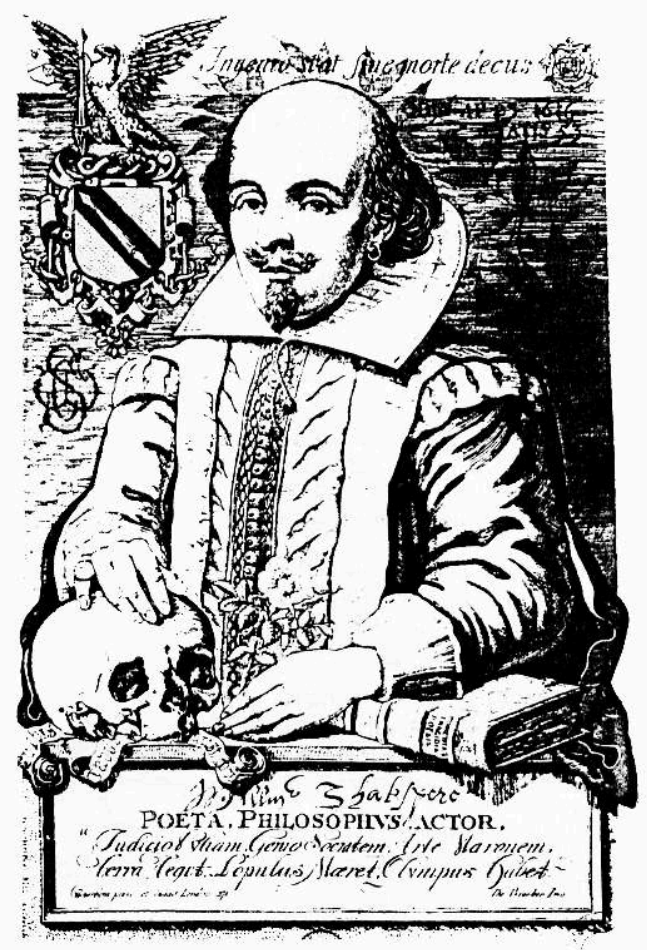

Il ne s'agit pas de proposer une bibliographie exhaustive mais de signaler les ouvrages qui ont guidé la réflexion lors du stage des metteurs en scène au mois d'août 1992.

BIRKETT J., Cymbeline in the twentieth Century. A study of major british productions, Birmingham, U. (Ph.D.), 1983-84.

CHATENET Jean, Shakespeare sur la scène française depuis 1940, Paris, Minard, 1962.

ELSON John (Ed.), Is Shakespeare still our contemporary? London-New-York, Routledge, 1989. 
FLUCHERE Henri, Shakespeare, Dramaturge élisabéthain, Paris, Gallimard, 1966.

FRYE Northrop, Shakespeare et son théâtre, Paris, Seuil, 1988.

GIRARD René, Shakespeare : les Feux de la Rampe, Paris, Grasset, 1990.

GRIVELET Michel, Shakespeare de A à Z (ou presque), Paris, Aubier, 1988.

HALIO Jay L., Understanding Shakespeare's Plays in Performance, Manchester University

Press, 1988.

JACQUOT Jean, Shakespeare en France. Mises en scène d'hier et d'aujourd'hui, Paris, Editions du Temps, 1964.

JONES-DAVIES Marie-Thérèse, Shakespeare. Le Théâtre du Monde, Paris, Balland, 1987.

котт Jan, Shakespeare, notre Contemporain, traduit du polonais par Anna Posner, Paris, Payot, 1978.

MANDER Raymond et MITCHENSON Joe, Hamlet through the ages. A pictorial record from 1709, London, Rockliff, 1955.

sCHOENBAUM S., William Shakespeare, a Documentary Life, Oxford, 1975.

SIBONY Daniel, Avec Shakespeare. Eclats et passions en douze pièces, Paris, Grasset, 1988. SICHERE Bernard, Le nom de Shakespeare, Paris, Gallimard, 1987.

Signature de Shakespeare figurant sur son testament daté du 25 mars 1616

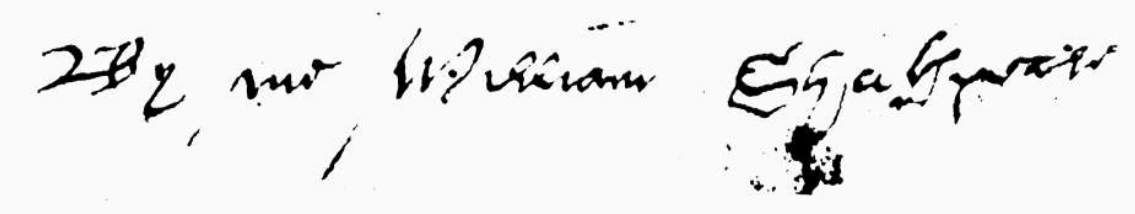

